\title{
Faith-Rooted Thinking on Matters of Public Concern: A Muslim Response to William L. Sachs
}

\author{
MARTIN NGUYEN*
}

The academic discipline of religious studies is, as Kate McCarthy puts it, a "project of secular critical inquiry"--hence one that gives pride of place to the maintenance of supposed religious neutrality in both research and teaching. I am trained as an academician and well accustomed to speaking and writing in an etic mode. Thus, for me to write Modern Muslim Theology: Engaging God and the World with Faith and Imagination was to take a deliberate and decisive step in a different disciplinary direction. ${ }^{1}$ In it, the voice I assume-the voice of a theologian - is fundamentally different from that of an Islamic studies scholar. Theologians, of course, are as rigorously trained as other academics; they employ critical, analytical methods. However, theirs is an emic mode: they speak and write confessionally, from a perspective of faith. Yet, regardless of the religion served, theology as a discipline is multifaceted. Its directions are many. My venture into theology, in many respects, exemplifies this. In whole or in part, it can be said to be a work of constructive pastoral, moral, or liturgical theology. In a recent conversation, Lucinda Mosher suggested that my book has also both expressed and encouraged public theology. The suggestion was striking as the characterization was new to me. What does it mean to do public theology? In this essay, I answer this

* Martin Nguyen is Associate Professor of Religious Studies, Director of Islamic Studies, and Faculty Chair for Inclusive Excellence at Fairfield University in Connecticut. His scholarship revolves around Muslim theology and ethics, Qur'anic hermeneutics, Sufism, and the intersection of race and religion. His most recent book, Modern Muslim Theology: Engaging God and the World with Faith and Imagination (Lanham, MD: Rowman \& Littlefield, 2018) presents a contemporary theology rooted in the practice of the religious imagination. He is also the author of Sufi Master and Qur'an Scholar: Abü'l-Qāsim al-Qushayrī and the Lațāififal-ishārāat (New York: Oxford, 2012), which explores the confluence of Sufism, theology, and Qur'anic hermeneutics in the life and works of an eleventh-century mystic and scholar.

1 Nguyen, Modern Muslim Theology. 
question by taking a close look at the notion of public theology through a decidedly Muslim lens.

First, what is public theology? Unsurprisingly, as is the case with much of the disciplinary discourse, many definitions are explicitly Christian in form and substance. However, Auburn Theological Seminary, which describes itself as an institution that equips leaders to "bridge religious divides, build community, pursue justice, and heal the world," defines public theology as "faith-rooted thinking on crucial issues of public concern." 2 As a Muslim, I find Auburn's definition compelling because it speaks to the need for our communities of faith to be responsive to a broader set of ethical, social, and political challenges. Public theology ought not be narrowly focused on the interests of Muslims alone, but should unfold in a way that is cognizant of and in solidarity with the wider publics in which Muslims find themselves engaged. Therefore, I also appreciate the description offered by E. Harold Brietenberg Jr., who calls public theology "theologically informed public discourse about public issues, addressed to the church, synagogue, mosque, temple or other religious body, as well as the larger public or publics, argued in ways that can be evaluated and judged by publicly available warrants as criteria."3 Such a disposition and definition, as recognized by William Sachs, speaks to the interconnected social web in which our communities of faith find themselves living and navigating.

Several vibrant examples of Muslim public theology come to mind. I would point to Najeeba Syeed at Claremont School of Theology as someone deeply in line with the definition from Auburn. Her intimate engagement with local communities, activist organizations, and fellow faith communities over a wide range of campaigns (both local and global) offers a compelling model for a public theology rooted in and animated by the Islamic tradition writ large. ${ }^{4}$ Similarly, I see the range of Farid Esack's work fitting well into Breitenberg's envisioned definition. While his early theological work was focused on the antiapartheid movement in South Africa, its public orientation continued to find new foci. For example, in later years he turned to

2 Auburn Theological Seminary, "Public Theologies," https://auburnseminary.org /public-theologies/.

3 E. Harold Brietenberg Jr., "To Tell the Truth: Will the Real Public Theology Please Stand Up," Journal of the Society of Christian Ethics 23 (2003): 66.

4 Claremont School of Theology, "Najeeba Syeed," https://cst.edu/academics /faculty/najeeba-syeed-miller/. 
address the HIV/AIDS pandemic in Africa, demarcating a significant new arc in his public theological work. ${ }^{5}$

As for my own endeavors, before the publication of Modern Muslim Theology, I was indeed engaging in "theologically informed public discourse about public issues." This is especially true of the many public lectures I have given on the relevance of Malcolm X for our time. ${ }^{6}$ But the publication of Modern Muslim Theology marked my formal assumption of the role of public theologian. In this book, I have defined theology, not in the traditional sense of highly reasoned Islamic scholasticism, but in the broad sense of reflection on all that fosters faith. ${ }^{7}$ As I see it, theology is both a "reflection on how we live in the world" and "a means for changing one's condition in the here and now, in the Hereafter, and-above all-before God." 8 Because it is framed as an exploration of "engagement of God and the World with Faith and Imagination," written in a manner accessible by people both within and outside my religious community, my book does serve, I believe, as solid preparation for addressing "issues of common interest and for the common good"9 - which is what public theology does.

One year after its publication, Modern Muslim Theology was the object of an online project of the Christian-Muslim Studies Network, hosted by the University of Edinburgh School of Divinity. Five scholars (one Christian, four Muslim) provided short reflections on some aspect of my book. These were posted on the Christian-Muslim Studies Network blog, one week at a time, during fall 2019. I then posted a response..$^{10} \mathrm{I}$ had written a book in a mode very different from my earlier works. I had penned it with multiple audiences in mind, unsure as to its reception on these many fronts. It was immensely gratifying, then, to have respected colleagues respond to it from their respective

5 See Farid Esack and Sarah Chiddy, eds., Islam and AIDS: Between Scorn, Pity and Justice (Oxford: Oneworld Publications, 2009).

6 See for example, Martin Nguyen, "Public Lecture: A Theology of Malcolm X; Protest Prayer, and the Stranger," UC Davis, Davis, CA, Oct. 19, 2017, https://mesa .ucdavis.edu/events/public-lecture-a-theology-of-malcolm-x-protest-prayer-and-the -stranger-by-martin-nguyen.

7 Nguyen, Modern Muslim Theology, 2-3.

8 Nguyen, Modern Muslim Theology, 17.

$9 \quad$ Here I adapt a definition put forth in purely Christian terms in the introduction to Katy Day and Sebastian Kim, eds., A Companion to Public Theology (Leiden: Brill, 2017), 2.

10 The series of blog posts can be found at Christian-Muslim Studies Network, the University of Edinburgh School of Divinity, http://christianmuslim.div.ed.ac.uk/blog/. 
positions and perspectives. Indeed, week by week, the themes of public theology quickly became manifest and evident.

I had written as a theologian, anchored to, and attentive to the needs and challenges of, a broadly conceived community of faith. In his post, Khalil Abdur-Rashid acknowledged both the pastoral and critical dimensions of my book. In it, I am indeed seeking to "popularize" and "domesticate" theology for wider and richer engagement. This engagement, however, must move beyond mimicry and cults of personality. The cultivation of faith, if it is to be both sustaining and transformative, must also be grounded in the lived experiences of the faithful. The imagination ought to be marshalled to bring to life the histories, memories, and everyday interactions carried closely by that community. While I have offered some of my own reimaginings in the book, I sincerely hope that the community of faith is able to develop other imaginative modes of faith that translate, transport, and transform.

Ebrahim Moosa, in evaluating the book's treatment of Muslim understandings of tradition, issued a note of caution. "Tradition," he argues, "is to a large extent a mode of civility." While much of my book was aimed at broadening, reinvigorating, and reframing tradition, the politicization of the concept is almost unavoidable. In his blog post, Moosa brought out poignantly the "how" of politicization in the cases of the medieval sage al-Ghazali and the black human rights activist Malcolm X. He also alluded to controversies that embroil the Muslim community even today. How one deals with contention and contestation in the face of tradition, then, matters greatly, for its consequences ripple through space, time, and multiple interrelated communities. We ought to respond, then, with a renewed cognizance of our agency and its impact. Nonetheless, contestation, I have argued, is the norm, rather than the exception. In fact, the life of the tradition continues because it has had to struggle through the vicissitudes of our histories and our ethical ambiguity. I may not know the future course that the tradition will take. I do, however, have faith in its ability to survive and overcome the community's most contentious fractures and divisive fissures, even in their "uncivil" manifestations.

The inward focus of Modern Muslim Theology was brought into sharp relief by a provocative question posed by Youshaa Patel concerning the interreligious implications of what I had written. I will admit that the book was purposely written with little to say explicitly about 
interreligious relations with other faith communities. My choice was deliberate. Too often, Muslim theology in the Euro-American Academy is only entertained when it is framed through its relationality to its primarily Christian, and sometimes Jewish, interlocutors. While such work has significance, it also reflects a prevailing power differential in the field of theology. Nevertheless, as Patel's own body of work explores, religious identity is perpetually formed in contradistinction to others. A fully articulated modern Muslim theology, then, must invariably tackle questions of interreligious solidarity and difference. How the balance between the two (solidarity vs. difference) might be struck, however, I leave open, for the moment deferring instead to the ongoing work of many others. After all, Modern Muslim Theology was never intended to settle matters. My goal, rather, was to inspire sincere discussion, prompt critical reflection, and activate religious imaginations for the sake of faith.

While I may not have explicitly engaged with other communities of faith in Modern Muslim Theology, the careful reader will in fact find implicit engagement at play. My own theological formation extends beyond the study of the Islamic tradition, past and present, and includes a number of Christian theologians. Underlying much of my writing are my responses to such voices, sometimes formulated in pointed contrast, sometimes formulated in agreement or at least resonance. Hence, my writing, though outwardly aimed at Muslim audiences, is also written in hopes of engaging the imaginations of other faith communities as well. Just as I have benefited immensely from my encounter with other theological traditions, I had hoped from its inception that my book project, in its commitment to doing Muslim theology, might serve as a similar vehicle of religious self-reflection for non-Muslim readers. I took Mosher's contribution to the ChristianMuslim Studies Network blog about Modern Muslim Theology, then, as a welcome affirmation of this aspiration. Confining her focus to my seventh chapter, entitled "Theology in Prostration," Mosher brought her Anglican Christian perspective to my consideration of prayer as a means of simultaneously turning to God and against the world. I find it heartening to imagine that the righteous engaged in this prayerful act of "turning" traverse many religious horizons.

In her thoughtful meditation on prayer, belief, and praxis, Mosher suggested that prayer shapes both "believing" and "behaving." This same appeal to prayer is present also in the piece by Sachs. He too 
sees the importance of a public theology that is informed by personal devotional practice. The practice of prayer has been in the past-and thus could be today - a basis for Christian-Muslim common ground, a means to find "a way to speak and to act in public life that was both appreciative of Islam and unstinting in Christian conviction."

I composed Modern Muslim Theology as one who participates regularly in various scholarly discourses. I also wrote this book in the hope of reaching broader publics, Muslim and otherwise. I never intended to settle matters. My goal, rather, was to inspire sincere discussion, prompt critical reflection, and activate religious imaginations for the sake of faith. My hope was to inspire others to think and live theologically. As demonstrated by the probing and thought-provoking reflections at the Christian-Muslim Network blog as well as the essays within this volume, there remains much work to be done in this regard. Yet, it is my genuine hope that this conversation continues. I hope readers will find my work useful for thinking through and appreciating the religious issues and problematics that Muslim communities face today. I hope they will be inspired to engage God and the world with faith and imagination. In sum, to the extent that our writing and witness drives toward and encourages "faith-rooted thinking on crucial issues of public concern," it is indeed public theology. 